\title{
Dermatophytosis by Trichophyton verrucosum in domestic feline - case report
}

\author{
Dermatofitose por Trichophyton verrucosum em felino doméstico - relato de caso \\ Dermatofitosis por Trichophyton verrucosum en felino doméstico - reporte de caso
}

Received: 01/14/2022 | Reviewed: 01/21/2022 | Accept: 01/29/2022 | Published: 01/30/2022

Danilo Rocha de Melo

ORCID: https://orcid.org/0000-0003-4793-7338 Universidade Federal do Oeste da Bahia, Brazil E-mail: danilomelo.vet@gmail.com

Juliany Nunes dos Santos

ORCID: https://orcid.org/0000-0001-9751-8663 Universidade Federal do Oeste da Bahia, Brazil E-mail:medvetjulianynunes@gmail.com

Evelyn Carla da Frota Rocha

ORCID: https://orcid.org/0000-0002-3752-3644

Universidade Federal do Oeste da Bahia, Brazil E-mail: evelynclfrota@gmail.com

Angélica Prado de Oliveira

ORCID: https://orcid.org/0000-0003-2290-4505 Universidade Federal do Oeste da Bahia, Brazil E-mail: angelicaprolmv@outlook.com Jôiciglecia Pereira dos Santos

ORCID: https://orcid.org/0000-0001-8409-1533 Universidade Federal do Oeste da Bahia, Brazil E-mail: joicigleciasantos@gmail.com

Valesca Ferreira Machado de Souza ORCID: https://orcid.org/0000-0001-5847-9593 Universidade Federal do Oeste da Bahia, Brazil E-mail: valescaferreira8@gmail.com

Valquíria Tatiele da Silva Rodrigues ORCID: https://orcid.org/0000-0002-8691-6671 Universidade Federal do Oeste da Bahia, Brazil E-mail: val.tatiele@gmail.com

Layze Cilmara Alves da Silva Vieira ORCID: https://orcid.org/0000-0002-1850-2768 Universidade Federal do Oeste da Bahia, Brazil E-mail: layze.cilmara@hotmail.com

\begin{abstract}
The present study aimed to report a case of dermatophytosis caused by Trichophyton verrucosum in a domestic feline. The patient was admitted to the University Veterinary Hospital of the Federal University of West Bahia, with dermatological complaints. On physical examination, alopecic lesions with an erythematous, hyperpigmented appearance and the presence of papules were noted, which were distributed throughout the body, with a greater predominance in the thoracic limbs, ventral region and head. Dermatological samples were collected from different areas of the body with lesions, which were sent for mycological culture and research for ectoparasites at the Laboratory of Clinical Analysis and Veterinary Microbiology of the same institution. The fungal examination showed the growth of colonies with a prominent center and flat periphery with salmon coloring and a subtly granular texture, demonstrating on microscopy hyaline septate fungal filaments, the presence of few piriform to ovoid shaped microconidia, in addition to several chlamydospores and hyphae with engorgement. terminal, compatible with "pearl chains", confirming a case of dermatophytosis by $T$. verrucosum. The literature approaches this fungus as a cause of disease in cattle and other ruminants, however there is still little information about its distribution and epidemiology in felines in Brazil, revealing the need for epidemiological studies in the area. It is concluded, therefore, that $T$. verrucosum infection in felines should be considered as a differential diagnosis of other dermatological conditions in the small animal clinic.
\end{abstract}

Keywords: Dermatological ailment; Veterinarian dermatology; Mycologic cultivation; Fungus.

\section{Resumo}

O presente estudo objetivou relatar um caso de dermatofitose causada por Trichophyton verrucosum em um felino doméstico. O paciente deu entrada no Hospital Veterinário Universitário da Universidade Federal do Oeste da Bahia, com queixas dermatológicas. Ao exame físico foram notadas lesões alopécicas de aspecto eritematoso, 
hiperpigmentado e presença de pápulas, que se distribuíam por toda a extensão corporal, havendo maior predominância nos membros torácicos, região ventral e cabeça. Foram colhidas amostras dermatológicas de diferentes áreas corporais com lesões, essas, encaminhadas para cultura micológica e pesquisa de ectoparasitas no Laboratório de Análises Clínicas e Microbiologia Veterinária da mesma instituição. Ao exame fúngico visualizou-se o crescimento de colônias de centro proeminente e periferias planas com coloração salmão e textura sutilmente granular, demonstrando na microscopia filamentos fúngicos septados hialinos, presença de poucos microconídeos de formato piriforme a ovoide, além de diversos clamidósporos e hifas com ingurgitação terminal, compatível com "cadeias de pérolas", confirmando um caso de dermatofitose por T. verrucosum. A literatura aborda esse fungo como causador de doença em bovinos e outros ruminantes, contudo ainda são escassas informações sobre a sua distribuição e epidemiologia em felinos no Brasil, revelando a necessidade de estudos epidemiológicos na área. Conclui-se, portanto, que a infecção por $T$. verrucosum em felinos deve ser considerada como diagnóstico diferencial de outras afecções dermatológicas na clínica de pequenos animais.

Palavras-chave: Afecção dermatológica; Dermatologia Veterinária; Cultivo micológico; Fungo.

\section{Resumen}

El presente estudio tuvo como objetivo reportar un caso de dermatofitosis causada por Trichophyton verrucosum en un felino doméstico. El paciente ingresó en el Hospital Veterinario Universitario de la Universidad Federal del Oeste de Bahia, con quejas dermatológicas. Al examen físico se aprecian lesiones alopécicas de aspecto eritematoso, hiperpigmentado y presencia de pápulas, las cuales se distribuyen por todo el cuerpo, con mayor predominio en miembros torácicos, región ventral y cabeza. Se recolectaron muestras dermatológicas de diferentes zonas del cuerpo con lesiones, las cuales fueron enviadas para cultivo micológico e investigación de ectoparásitos en el Laboratorio de Análisis Clínicos y Microbiología Veterinaria de la misma institución. El examen fúngico mostró el crecimiento de colonias con un centro prominente y periferia plana con coloración asalmonada y una textura sutilmente granular, demostrándose microscópicamente filamentos fúngicos septados hialinos, la presencia de pocas microconidias de forma piriforme a ovoide, además de varias clamidosporas e hifas. con ingurgitación terminal, compatible con “cadenas de perlas", confirmando un caso de dermatofitosis por T. verrucosum. La literatura aborda este hongo como causante de enfermedad en bovinos y otros rumiantes, sin embargo, aún hay poca información sobre su distribución y epidemiología en felinos en Brasil, lo que revela la necesidad de estudios epidemiológicos en el área. Se concluye, por tanto, que la infección por $T$. verrucosum en felinos debe considerarse como diagnóstico diferencial de otras patologías dermatológicas en la clínica de pequeños animales.

Palabras clave: Condición dermatológica; Dermatología Veterinaria; Cultivo micológico; Hongo.

\section{Introduction}

Dermatological disorders show high prevalence in small animal, and they are the cause of one of the main problems that motivate the search for a veterinarian (Gasparetto et al., 2013). Within this scenario, diseases involving fungi, especially dermatophytes, are important not only for their high occurrence but also the zoonotic transmission capacity, which represents a problem to the Saúde Única (Neves et al., 2018; Andrade \& Rossi, 2019).

Dermatophytoses are superficial cutaneous mycosis caused by keratinophilic fungi from the dermatophyte group, which are distributed in the genera Trichophyton, Epidermophyton, Microsporum, Nannizzia, Paraphyton, Lophophyton and Arthroderma (Farias et al., 2016; Hoog et al., 2017). In dogs and cats, they are highlighted through infeccions by the species Microsporum canis, Microsporum gypseum and Trichophyton mentagrophytes, $M$. canis the most frequent in cases involving domestic felines (Neves et al., 2011; Castro et al., 2016; Dias et al., 2017).

Due to the natural habitat and the development spot, the dermatophyte fungi can be classified into three main categories: geophilic, anthropophilic and zoophilic, and they are found in the soil, humans and animals, respectively (Farias et al., 2016; Neves et al., 2018; Andrade \& Rossi, 2019). T. verrucosum is a zoophilic dermatophyte species associated to infectious cases in ruminants (Farias et al., 2016), and rarely described as the causative agent of dermatopathies in dogs and cats. Furthermore, the present study aimed to report a dermatophytosis case caused by T. verrucosum in a domestic feline (Felis catus). 


\section{Case Report}

A three-year-old, crossbred male cat, was checked in the Veterinary University Hospital (VUH) from the Universidade Federal do Oeste da Bahia (UFOB) with dermatological lesions complaint. The owner reported the presence of areas of alopecia which were observed throughout a whole week, emphasizing that the animal had not presented pruritus in those regions. The patient lived in an urban region of the municipality Barra, located in the state of Bahia, Brazil, and had access to the street and contact with stray animals, with history of fights and constant wounds. There was no history of vaccination or vermifugation.

During the physical exam the patient showed normal vital functions, a good general physical status and absence of ectoparasites. In the evaluation of the integumentary system, one could observe alopecic lesions of erythematosus aspect, hyperpigmented and with the presence of papules, which were spread throughout the body extension, with a higher predominance in the thoracic members, ventral region and head (Figure 1A and 1B). In addition, the main clinical suspicions included mycotic dermatitis and scab infestation.

Figure 1: Dermatological lesions present in a feline attended at the Veterinary University Hospital from the Universidade Federal do Oeste da Bahia.

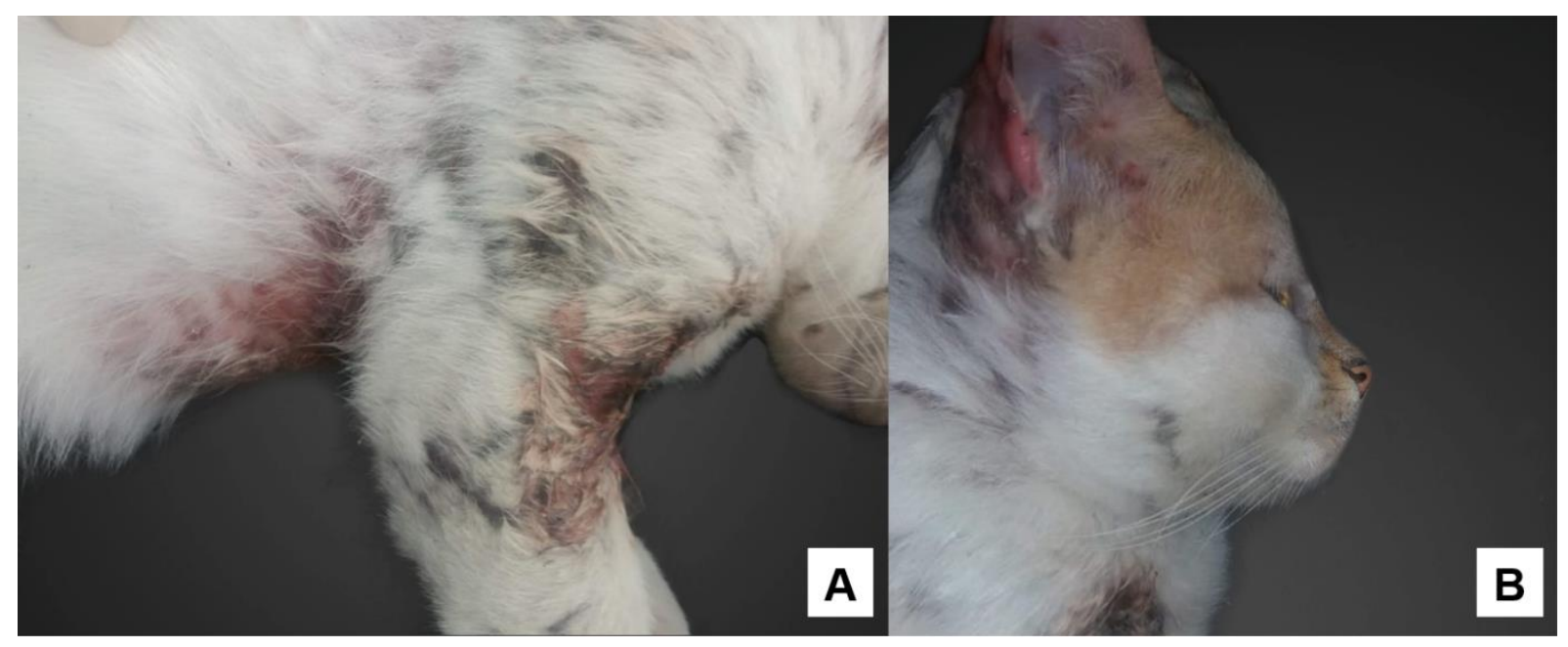

A) Alopecic dermatological lesions of erythematosus aspect, hyperpigmented and with the presence of papules, spread in the thoracic members and thoracic region. B) Alopecic dermatological lesions of erythematosus aspect, hyperpigmented and with the presence of papules, present in the region of the face and ear. Source: Authors.

In order to confirm the diagnostic, a cutaneous shaving was carried out with the aim of researching for mites and mycologic culture with fungal identification. The samples had fur, scabs and skin, including the lesion edges and they were collected from the different affected areas, through the blades of sterile scalpels (Hnilica \& Patterson, 2016), stored and sent to the Laboratory of Clinical Analyses and Veterinarian Microbiology from the HVU/UFOB, so they could be adequately processed.

On the skin shaving in search for mite, two drops of potassium hydroxide $(\mathrm{KOH}) 10 \%$ were added to make the visualization of possible parasitic structures easier, followed by reading using a common optical microscope with objective lens 10 and 40X (Hnilica \& Patterson, 2016), revealing negative sample for scabs.

In the mycotic cultivation the samples were sown in Petri dishes containing Dextrose Sabouraud Agar mean with chloramphenicol and incubated at $\left(25\right.$ to $\left.30{ }^{\circ} \mathrm{C}\right)$ in aerobiosis, the growth being followed daily for up to 15 days. The sample presented positive growth for the colonies with prominent center and flat peripheries with salmon color with slightly granular 
texture (Figure 2A). In order to assess the microscopic characteristics the microcultivation technique in dish was used (Anvisa, 2013), which showed hyaline septated fungal filaments, presence of few microconidia of piriform to ovoid format as well as several chlamydospores and hyphae with terminal engorgement, compatible with the "pearls chains" (Figure 2B), thus confirming Trichophyton verrucosum.

Figura 2: Isolation of Trichophyton verrucosum in feline dermatophytosis.
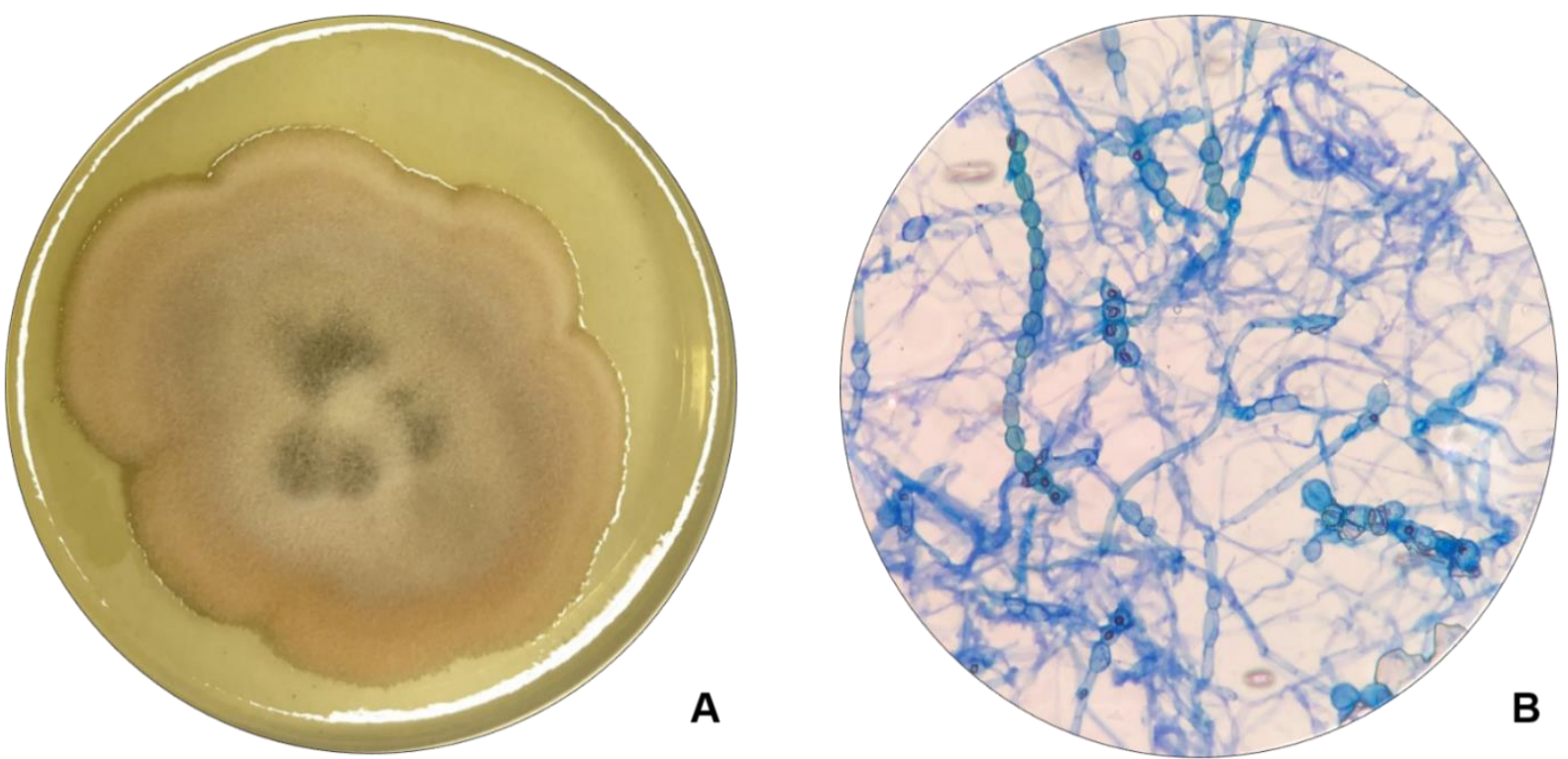

A) Macroscopy - Myselian colonies with prominent center and flat peripheries with salmon color, slightly granular texture in Saboraud Dextrosis agar mean. B) Microscopy - Hyaline septated fungal filaments, presence of few microconidia of piriform to ovoid format, in addition to several chlamydospore and hyphae with terminal engorgement, compatible to the "pearls chains". Obj. 40x. Methylene blue 1\%. Source: Authors.

Treatment was carried out using shampoo (containing Ketoconazole $2 \%$ and Chlorhexidine $0.5 \%$ ) and the return of the patient was scheduled for a new assessment after 10 days in order to verify the evolution of the clinic status and the need to conduct new therapeutical strategies. Before the return date the animal passed away due to a car accident, therefore it was not possible to do the follow up regression in the dermatological status.

After the diagnostic conclusion the owner of the animal was questioned about the possibility of the animal having contact with either bovines or rural area, but these claims were denied. Nevertheless, the owner confirmed that he owned a rural property where he raised ruminants and that he visited them constantly. However, those animals never presented any kind of dermatological problems. In addition, the same individual reported the presence of lesions similar do the ones present in the studied feline during the same period of time in his body.

\section{Discussion}

The mycological cultivation and the use of the fungus micro cultivation technique, as suggested (CLSI, 2003; Vyzantiadis et al., 2012; Yeva et al., 2014), have allowed the isolation and identification of the dermatophyte Trichophyton verrucosum, with colony features and microscopic structures similar to the ones described in the literature (Silveira et al., 2003; Farias et al., 2016; Larone \& Larone, 1987; De Hogg et al., 2004).

The clinical relevance of the dermatophytosis is quite explained within the scientific community. They represent formidable causes of veterinary service as well as the increasing and important discussion within the perspective of One Health System, especially due to the zoonotic transmission capacity among most of the involved agents (Neves et al., 2018; Andrade 
\& Rossi, 2019). Specifically in felines, M. canis and M. gypseum present significative occurrence (Dias et al., 2017) however, there are few papers that elucidate the isolation of $T$. verrucosum which causes either dermatophytosis in dogs and cats or are still present in the fur of asymptomatic animals.

The species T. verrucosum is considered to be present in most cases of dermatophytosis in ruminants, having its elevated occurrence caused by its highly contagious capacity, which also makes the transmission among animals as well as humans easier. In international papers this importance and the occurrence of the agent have been well documented, showing reports of disease outbreak (Swai \& Sanka, 2012) as well as outbreaks in cases of co-infection with other dermatophytes species (Lagowski et al., 2020). In Brazil the papers that signal such isolation are rare. Despite the fact that the dermatophytes population have expected hosts which act as agent reservoirs (Farias et al., 2016), the work described in this paper shows the infection capacity variability of these species, especially the $T$. verrucosum. The possibility that this specific-species affinity may have something to do with the keratinases and other enzymes regarding each fungal species when responding to the substrate of each host (Gnat et al., 2019) has already been taken into consideration.

An in vitro study which evaluated the host range of $T$. verrucosum through keratinolytic dependent-substrate phenotypic analysis activity has confirmed higher tropism in the fungal species for bovines and a lower activity for the keratolytic enzymes in the fur of cats, even if they were present (Gnat et al., 2019). Nonetheless, some international papers point out their isolations in dogs and cats (Moosavi et al., 2019; Long et al., 2020), based on their capacity of infecting small animals. In addition, Reis-Gomes et al. (2018), have shown the occurrence of the mentioned species in uncommon hosts, such as equines, which instigates the wide possibility of hosts for T. verrucosum. Moreover, a Brazilian study about the distribution of dermatophytes in the environment has revealed the isolation of $T$. verrucosum in 7,6\% of the samples coming from urban areas in the state of Paraíba, Brazil (Pontes et al., 2013), indicating its elevated adaptability to different conditions.

A percentage of $1,1 \%$ T. verrucosum isolation in dogs was reported in a study in the South of England done through the analysis of the mycological diagnostics throughout 26 years in a veterinary laboratory (Long et al., 2020). Furthermore, a research carried out in a rural area in Iran has confirmed its presence in $86.66 \%$ of the studied cats, which did not present either clinical signs of dermatophytosis or dermatological problems. The authors associated this unexpected result with the proximity of the cats to ruminants (Moosavi et al., 2019). In the case here reported we did not identify direct proximity of the feline with either farm animals or ruminants. In Brazil, little is reported in the literature about infections in domestic cats caused by $T$. verrucosum, Andrade Junior et al. (2017), reports a case of isolation of T. verrucosum in a domestic feline, demonstrating the need for more research on the occurrence of this agent in this species, mainly emphasizing the importance of being careful with the time of analysis of cultures suspected of dermatophytosis, since this fungus has slow growth.

In ruminants the clinical presentation of the dermatophytosis by $T$. verrucosum is seen by round alopecic lesions, scabs of dry aspects and well adhered, besides variable pruritus, spread most of the times in a focal way, with the possibility of becoming disseminated (Farias et al., 2016; Lagowski et al., 2020). In the present clinical case, the lesions were distinct from the classic form of dermatophytosis, including the clinical presentation of the infections by T. verrucosum in bovines. One was not able to verify the presence of dry scabs and lesions of round aspect, but lesions of humid aspect with the presence of papules, which could be associated with the agent pathogenicity as well as to the secondary infections.

In this report, regardless of the feline's owner deny the occurrence of likely dermatophytosis in the ruminants living in his rural property, there is the probability they harbored the fungus, since even asymptomatic animals can act as the source of infection, as shown by Surpilli et al. (2018), who isolated T. verrucosum in $10 \%$ of the bovines and in $33.3 \%$ of the ovine without apparent clinical signs and Silveira et al. (2003), who showed a percentual of 1,2\% of positive healthy bovine skin samples for such pathogen. Therefore, it is not possible to discard that the probable source of infection comes from the animals raised by the feline's owner. The zoonotic transmission of $T$. verrucosum is suggested in the literature as quite frequent (Farias 
et al., 2016), and apparently such transmission becomes more frequent when the population of people has direct contact with the ruminants, for example, animal breeders and caretakers (Néji et al., 2011). The patient's owner from this report presented skin lesions compatible to the ones in the animal and in addition he had contact with ruminant breeding, which makes the direct transmission from the owner to the feline possible. Another possibility is the indirect transmission through fomites and contaminated objects, which are also important way of pathogen maintenance among the hosts (Farias et al., 2016; Neves et al., 2018). Furthermore, the animal's habit of living free, predisposes the contact with infected environments and animals, facts which are unknown to their owners.

In the literature, several studies confirm the zoonotic potential of dermatophyte fungi, such as Cafarchia et al. (2006), Bier et al. (2013) and Waller et al. (2014), who analyzed samples from human beings with a positive diagnosis for the disease. Corroborating these studies, Wael et al. (2015), in their study, observed that $7.2 \%$ of the analyzed samples of human beings tested positive for T. verrucosum, where they were people who had cattle, sheep and goats. Aquino et al. (2003), in their study carried out in João Pessoa, observed that T. verrucosum was found in the fourth position among the positive samples for dermatophytosis in human beings, representing $10 \%$ of the observed cases.

Santos et al. (2021), observed in their study with dogs and cats, percentages representing $14.2 \%$ of positive samples for fungi, also demonstrating that a relevant percentage of their owners also reported having similar skin lesions, fact that can be explained by the close interaction between the owners and their animals, which facilitates the zoonotic transmission of these agents, highlighting the fact that many of these owners were unaware of the term zoonosis, revealing the need for investment in health education, addressing issues related to One Health, aiming at the prevention of occurrence of these diseases in animals and consequently in humans.

\section{Conclusion}

Literature is still scarce regarding the distribution and epidemiology of $T$. verrucosum in the national territory, reinforcing thus the necessity of studies of epidemiological character in Brazil. According to the present reported case and comparing that with the available data in the literature, the zoophilic dermatophyte in question proved to be the cause of dermatophytosis in domestic cats without history of direct contact with either rural environment or ruminant breeding, which reinforces the message that this species should be considered as one of the possibilities of being etiological agents in the clinic routine of small animals.

Also emphasizing the importance of this disease, in the context of One Health, given the increasing occurrence of the disease in humans, due to the increasingly close contact between humans and animals, which makes it necessary to carry out more studies on the prevalence of T. verrucosum in humans.

\section{References}

Andrade, V. \& Rossi, G. A. M. (2019). Dermatofitose em animais de companhia e sua importância para a Saúde Pública - Revisão de Literatura. Revista Brasileira de Higiene e Sanidade Animal, 13(1), 142-155.

Andrade Junior, A. G., Scariot, A. C. A., Waller, S. B, Silva, A. L, Martins, O. A., \& Reis Gomes, A. (2017). Isolamento de Trichophyton verrucosum de lesão em gato. In: XXVI Congresso de Iniciação Científica da Universidade de Pelotas, 2017, Pelotas. Anais 2017.

Aquino, P. M. L. P. D., Lima, E. D. O., \& Farias, N. M. P. D. (2003). Tinea Capitis in João Pessoa: A social and economic view. Anais Brasileiros de Dermatologia, 78, 713-717.

Bier, D., de Farias, M. R., Muro, M. D., Soni, L. M. F., Carvalho, V. O., \& Pimpão, C. T. (2013). Isolamento de dermatófitos do pelo de cães e gatos pertencentes a proprietários com diagnóstico de dermatofitose. Archives of Veterinary Science, 18(1).

Brasil. Agência Nacional de Vigilância Sanitária. (2013). Microbiologia Clínica para o Controle de Infecção Relacionada à Assistência à Saúde. Módulo 8: Deteç̧ão e identificação de fungos de importância médica. Anvisa, 30-31. 
Castro, L. S. O., Mourão, G. C., Silva, T. F. P., Silva, L. D. M., \& Costa, P. P. C. (2016). Dermatofitose em gato: Relato de caso. Revista Brasileira de Higiene e Sanidade Animal, 10(3), 484-93.

Cafarchia, C., Romito, D., Capelli, G., Guillot, J., \& Otranto, D. (2006). Isolation of Microsporum canis from the hair coat of pet dogs and cats belonging to owners diagnosed with M. canis tinea corporis. Veterinary dermatology, 17(5), 327-331.

CLSI. (2003). Clinical and Laboratory Standards Institute Quality Manual. (3a ed.), CLSI.

De Hoog, G. S., Guarro, J., Gené J. \& Figueiras, M. J. (2004). Atlas of Clin.Fungi. Ultrech \& Réus: Centralbureal voor Schimmelcultures to $\backslash$ Universitat Rovira, Virgilli.

Dias, T. P., Waller, T. S. B., Silva, A.L., Serra, E.F., Martins, O. A., Gomes, A. R., Faria, R. O. \& Meireles, M. C. A. (2017). Microsporum gypseum como agente etiológico de dermatofitose em felino (felis catus). Science and Animal Health, 5(3), 251-259.

Farias, M. R., Costa, F. V. A., Giuffrida, R. (2016). Dermatofitose em animais de produção e de companhia. In: Megid, J., Ribeiro, M.G., Paes, A.C. Doenças infecciosas em animais de produção e de companhia. Roca, 887-905.

Gasparetto, N. D., Trevisan, Y. P. A., Almeida, N. B., Neves, R. C. S. M., Almeida, A. B. P. F., Dutra,V., Colodel, E. M. \& Sousa, V. R. F. (2013). Prevalência das doenças de pele não neoplásicas em cães no município de Cuiabá, Mato Grosso. Pesquisa Veterinária. Brasileira, 33(3), 359-362.

Gnat, S., Łagowski, D., Nowakiewicz, A., \& Zięba, P. (2019). The host range of dermatophytes, it is at all possible? Phenotypic evaluation of the keratinolytic activity of Trichophyton verrucosum clinical isolates. Mycoses, 62(3), 274-283.

Hnilica, K. A. \& Patterson, A. P. (2016). Diagnostic Techniques. In: Hnilica, K.A. and Patterson, A.P. Small animal dermatology: a color atlas and therapeutic guide. $4^{\text {a }}$ ed. Elsevier Health Sciences, St. Louis, Missouri. 30-44

Hoog, G. S., Dukik, K., Monod, M., Packeu, A., Stubbe, D., Hendrickx, M., \& Gräser, Y. (2017). Toward a novel multilocus phylogenetic taxonomy for the dermatophytes. Mycopathologia, 182(1-2), 5-31.

Lagowski, D., Gnat, S., Nowakiewicz, A., Osińska, M., Trościańczyk, A., \& Zięba, P. (2020). Dermatophytosis with concurrent Trichophyton verrucosum and T. benhamiae in calves after long-term transport. Veterinary Dermatology, 31(5), 414-e111.

Larone, D. H., \& Larone, D. H. (1987). Medically important fungi: a guide to identification (196, 203). Elsevier.

Long, S., Carveth, H., Chang, Y. M., O'Neill, D., \& Bond, R. (2020). Isolation of dermatophytes from dogs and cats in the South of England between 1991 and 2017. Veterinary Record, 187(10), e87-e87.

Moosavi, A., Ghazvini, R.D., Ahmadikia, K., Hashemi, S.J., Geramishoar, M., Mohebali, M., Yekaninejad, M.S., Bakhshi, H. and Khodabakhsh, M. (2019). The frequency of fungi isolated from the skin and hair of asymptomatic cats in rural area of Meshkin-shahr-Iran. New England Journal of Medicine, 19(1):1418.

Néji, S., Makni, F., Cheikrouhou, F., Sellami, H., Trabelsi, H., Marrakchi, S., Boudaya, S., Turki, H., \& Ayadi, A. (2011). Dermatomycosis due to Trichophyton verrucosum in Sfax-Tunisia. Journal de mycologie medicale, 21(3), 198-201.

Neves, R. D. C. D. S. M., Cruz, F. A. C. S. D., Lima, S. R., Torres, M. M., Dutra, V., \& Sousa, V. R. F. (2011). Retrospectiva das dermatofitoses em cães e gatos atendidos no Hospital Veterinário da Universidade Federal de Mato Grosso, nos anos de 2006 a 2008. Ciência Rural, 41, 1405-1410.

Neves, J. J. A., Paulino, A. O., Vieira, R. G., Nishida, E. K., \& Coutinho, S. D. A. (2018). The presence of dermatophytes in infected pets and their household environment. Arquivo Brasileiro de Medicina Veterinária e Zootecnia, 70, 1747-1753.

Pontes, Z. B. V. D. S., Oliveira, A. C. D., Guerra, F. Q. S., Pontes, L. R. D. A., \& Santos, J. P. D. (2013). Distribution of dermatophytes from soils of urban and rural areas of cities of Paraiba state, Brazil. Revista do Instituto de Medicina Tropical de São Paulo, 55, 377-383.

Reis-Gomes, A., Marcolongo-Pereira, C., Sallis, E. S. V., Bruhn, F. R., Faria, R. O., Schild, A. L., \& Meireles, M. C. (2018). Epidemiologia de micoses, pitiose e micotoxicoses em equinos no sudeste do Rio Grande do Sul. Pesquisa Veterinária Brasileira, 38, 1110-1116.

Santos, J. N., Rocha, E. C. F., Santos, J. P., Souza, V. F. M., Melo, D. R., Almeida, J. C., Carneiro, I. O., Vieira, L.C.A.S. (2021). Epidemiological, clinical and laboratory profile of dermatopathies of household dogs and cats in a semi-arid region of Northeast Brazil. Research, Society and Development, 10(14).

Silveira, E. S., Oliveira, M.N., Souza, L. L., Faria, R. O., Cleff, M. B., \& Meireles, M. C. A. (2003). Trichophyton verrucosum em bovinos com pele hígida e com lesões. Acta Scientiae Veterinariae, 31(1), 45-49.

Surpilli, F. O., Gatto, I. R. H., Frias, D. F. R., \& Kozusny-Andreani, D. I. (2018). Ocorrência de dermatófitos em tegumento de bovinos e ovinos hígidos. Arquivos de Ciências Veterinárias e Zoologia da UNIPAR, 21(1).

Swai, E. S., \& Sanka, P. N. (2012). Bovine Dermatophytosis Caused by Trychophyton verrucosum: A case report. Veterinary World, 5(5), 297-300.

Vyzantiadis, T. A. A., Johnson, E. M., Kibbler, C. C. (2012). From the patient to the clinical mycology laboratory: how can we optimise microscopy and culture methods for mould identification? Journal of clinical pathology, 65(6), 475-483.

Wael, F., Tayel, A. A., Mohamed, R. A., El-Kordy, D. M., El-Kady, N. N., \& Samir, A. (2015). Mixed rearing correlates with the existence of Trichophyton verrucosum pathogens in humans. Dermatologica Sinica, 33(3), 130-133.

Waller, S. B., dos Reis-Gomes, A., Cabana, Â. L., de Faria, R. O., Meireles, M. C. A., \& de Mello, J. R. B. (2014). Microsporose canina e humana-um relato de caso zoonótico. Science And Animal Health, 2(2), 137-146.

Yeva, R., Tetsuhiro, M., Tohru, G., \& Anis, K. (2014). Modified slide culture method for faster and easier identification of dermatophytes. Microbiology indonesia, 8(3), 135-139. 